\title{
A steroidal saponin form Paris vietnamensis (Takht.) reverses temozolomide resistance in glioblastoma cells via inducing apoptosis through ROS/PI3K/Akt pathway
}

\author{
Shan Zhang ${ }^{1, \S}$, Yang Liu ${ }^{2, \S}$, Yunyang $\mathrm{Lu}^{2, \S}$, Hua Li' ${ }^{2}$, Yuqiang $\mathrm{Ji}^{3}$, Fei Fang ${ }^{3}$, Haifeng Tang ${ }^{1,2, *}$, \\ Pengcheng Qiu ${ }^{2, *}$
}

${ }^{1}$ School of Pharmacy, Shaanxi University of Chinese Medicine, Xianyang, China;

${ }^{2}$ Institute of Materia Medica, School of Pharmacy, Fourth Military Medical University, Xi'an, China;

${ }^{3}$ Central Laboratory of Xi'an No.1 Hospital, Xi'an, China.

SUMMARY Glioblastoma is one of the most difficult cancers to treat with a 5-year overall survival rate less than $5 \%$. Temozolomide (TMZ) is an effective drug for prolonging the overall survival time of patients, while drug-resistance is an important clinical problem at present. Pennogenin-3$\alpha$-L-rhamnopyranosyl-( $1 \rightarrow 4)$-[ $\alpha$-Lrhamno-pyranosyl- $(1 \rightarrow 2)]$ - $\beta$-D-glucopyranoside (N45), a steroidal saponin, was isolated from the rhizomes of Paris vietnamensis (Takht.), which is used as a Traditional Chinese Medicine and has been reported to possess preclinical anticancer efficacy in various cancer types. However, the mechanism of the inhibition of N45 on glioblastoma cells and its possible application in the treatment of chemotherapy-resistant glioblastoma cells are still unknown. In this study, we use cellular methodological experiments including cell counting kit-8 (CCK-8) assay, terminal deoxynucleotidyl transferase dUTP nick end labeling (TUNEL) staining assay, flow cytometry assay, transmission electron microscopy (TEM) and Western blot. The results show that N45 significantly suppresses the proliferation of glioblastoma cells and TMZ-resistant glioblastoma cells (U87R) by inducing mitochondrial apoptosis through reactive oxygen species (ROS)/phosphoinositide 3-kinase (PI3K)/Akt signal pathway, and the N-acetyl-L-cysteine (NAC) combined with $\mathrm{N} 45$ effectively reduced N45-mediated apoptosis and reversed the inhibition of PI3K/Akt signal pathway. In addition, N45 decreased the drug-resistance by down-regulation of nuclear factor kappa-B p65 (NF-kB p65) to attenuate $\mathrm{O}^{6}$-methylguanine-DNA methyltransferase (MGMT) in TMZ-resistant glioblastoma cells (U87R). Our findings proved that N45 might be a potential therapeutic agent against glioblastoma and TMZ-resistant glioblastoma, promising to be a potential agent to reduce drug resistance.

Keywords Paris vietnamensis (Takht.) (N45), glioblastoma cells, temozolomide resistance, apoptosis, ROS/ PI3K/Akt pathway

\section{Introduction}

Glioblastoma is the most common malignant primary brain tumor in adults, and the high rate of mortality and relapse makes it remain to be one of the most difficult cancers to treat with a 5-year overall survival rate less than $5 \%(1)$. Despite this the treatment has evolved from only single surgery to a combination treatment of surgery with radiotherapy and chemotherapy, and the average survival time is only 12-15 months for the patient with glioblastoma. Especially for elders, the survival period is less than 12 months $(2,3)$. However, commonly used clinical drugs cannot effectively prolong the survival time of patients. Tumor recurrence limits the efficacy of glioblastoma treatment, which is mainly associated with the drug-resistance property of glioblastoma cells (4). Temozolomide (TMZ) is a clinical chemotherapy drug with broad-spectrum antitumor activity. The cytotoxicity of temozolomide is mainly achieved by methylation of $\mathrm{O}^{6}$-guanine. However, because of the single mechanism of action and widespread drug-resistance its drug efficacy is limited (5). Therefore, it is urgent to develop new therapeutic drugs for glioblastoma treatment.

Natural products are a source of leading compounds for new drug development, especially for tumor 
treatment. For example, taxol, a natural compound, was first isolated from the bark of Taxus brevifoliac and has showed significant therapeutic effect against several tumors, such as ovarian cancer, breast cancer and so on $(6,7)$. Steroidal saponins, a group of natural products consisting of a steroidal aglycone moiety and oligosaccharide moiety, with a character of resource diversity, structural diversity and bioactive diversity, have become an important branch of natural drug discovery. Studies have shown that steroidal saponins exhibit multiple pharmacological effects, such as anti-inflammatory, anti-cancer, antiviral, immune regulatory and cardiovascular protection, among which anti-cancer is the most attractive one $(8-10)$. For instance, ginsenoside $\mathrm{Rg} 3$ demonstrates significant anti-cancer effects on various tumors, such as gastric cancer (11), liver cancer (12), ovarian cancer (13), lung cancer (14), and melanoma (15).

The genus Paris (Liliaceae) is a famous Traditional Chinese Medicine listed in the Chinese Pharmacopoeia, with 32 species and more than 10 varieties (16). Paris vietnamensis (Takht.) is one of the varieties of the genus Paris, mainly distributed in Guangxi and Yunnan provinces of China and in North Vietnam (17). Modern phytochemical and pharmacological research showed that the genus Paris had anti-tumor effects and steroidal saponins were the chief active components. For example, Polyphyllin I (D), Polyphyllin II, Polyphyllin III, Polyphyllin VII and paris saponin $\mathrm{H}$, which were isolated from Paris, have significant anti-cancer effects, including ovarian cancer, liver cancer, stomach cancer, colon cancer, breast cancer, osteosarcoma, melanoma and glioblastoma $(18,19)$. Liu et al. reported Polyphyllin I induced G2/M phase arrest and apoptosis in U251 human glioblastoma cells via JNK signaling pathway (20). Pang et al. discovered that Polyphyllin VII promoted glioblastoma cells apoptosis and autophagic cell death through ROSinhibited Akt activity (21). These studies demonstrate the potential of the genus Paris in anti- glioblastoma studies.

N45 is a steroidal saponin isolated from the rhizomes of Paris vietnamensis, and the structures were identified as pennogenin-3- $\alpha$-L-rhamnopyranosyl$(1 \rightarrow 4)$ - $[\alpha$-Lrhamnopyranosyl- $(1 \rightarrow 2)]-\beta$-D-glucopyranoside. Our previous study revealed that N45 exhibited significant cytotoxic effects against glioblastoma cell lines U87 and U251 (22). However, the mechanism and the possible application in the treatment of chemotherapy-resistant glioblastoma are still unknown. This study was designed to evaluate the antitumor mechanism of N45 on glioblastoma cells and TMZ-resistant glioblastoma cells, and examine the correlation between apoptosis and the ROS/PI3K/ Akt signal pathway. Besides, we also investigated the mechanism of N45 reversal of drug resistance in glioblastoma cells.

\section{Materials and Methods}

\subsection{Materials}

TMZ was supplied by Yuanye Biological Co., Ltd. (Shanghai, China). The Cell Counting Kit-8 (CCK-8) and the terminal deoxynucleotidyl transferase dUTP nick end labeling (TUNEL) assay cell death kit were purchased from Seven-sea Biotech (Shanghai, China). $\mathrm{N}$-acetyl-L-cysteine (NAC) was supplied by Solarbio (Beijing, China). ROS assay kit was purchased from Beyotime Biotechnology (Shanghai, China).

\subsection{Cell culture}

Human glioblastoma cell lines U251 and U87 were purchased from the Chinese Academy of Sciences Cell Bank (Shanghai, China). TMZ-resistant variant cell line (U87R) was obtained by exposing U87 to an increasing concentration of TMZ $(1,5,25,50,100,200 \mu \mathrm{g} / \mathrm{mL})$ for 6 months. The cell lines were cultured in DMEM (Corning, Beijing, China) supplemented with 10\% FBS (Ausbian, Harbin, China), maintained at $37^{\circ} \mathrm{C}$ with $5 \%$ $\mathrm{CO}_{2}$. The medium was changed every 3 days.

\subsection{Cell proliferation assay}

The logarithmic phase cells were seeded in 96-well plates at a density of $5 \times 10^{3}$ cells/well. After $24 \mathrm{~h}$, the cells were incubated with different doses $(40,20,10$, $5,2.5,1.25,0.6250 .3125 \mu \mathrm{g} / \mathrm{mL})$ of $\mathrm{N} 45$ for $24 \mathrm{~h}$. Four replicated wells were used for each experimental condition. After treatment, cell proliferation and cytotoxicity were assessed using CCK-8, $10 \mu \mathrm{L}$ CCK8 was added to each well and incubated at $37^{\circ} \mathrm{C}$ for $2 \mathrm{~h}$, measuring the absorbance at a wavelength of $450 \mathrm{~nm}$ using a microplate reader.

\subsection{TUNEL assay}

Cells were cultured on cell plates coated with PolyL-Lysine (PLL) and incubated $24 \mathrm{~h}$. After incubation with N45 for $24 \mathrm{~h}$, and phosphate-buffered saline (PBS) washing twice, the cells were incubated with fluorescein isothiocyanate (FITC)-dUTP for 15 minutes at room temperature in the dark. Thereafter, the cells were washed twice more with PBS. Then using a fluorescence microscope obtained five random fields of vision, recorded apoptotic cells (green fluorescence cells) and normal cells (red fluorescence cells), and calculated the apoptosis rate.

\subsection{Cell apoptosis analysis}

The logarithmic phase cells were cultured on 6-well plates at density of $2 \times 10^{5}$ cells and incubated for $24 \mathrm{~h}$, The cells were collected after treatment with different 
doses $(0,2,4 \mu \mathrm{g} / \mathrm{mL})$ of $\mathrm{N} 45$ for $24 \mathrm{~h}$, three replicate wells were used for each experimental condition. Then washed twice in cold PBS $\left(4^{\circ} \mathrm{C}\right)$, cells apoptosis were performed using Annexin V-FITC/ propidine iodide (PI) double staining. The result of AV/PI-positive cells was evaluated with a flow cytometer (BD FACSCalibur, USA).

\subsection{Transmission electron microscopy analysis}

Cells were fixed in 2\% glutaraldehyde for $2 \mathrm{~h}$ and washed twice with PBS for $10 \mathrm{~min}$. Then fixed in $1 \%$ $\mathrm{OsO}_{4}$ for $2 \mathrm{~h}$. After gradient dehydration with ethanol, the cells were embedded in epoxy resin and cut into 50-60 nm sections. Sections were stained with uranyl acetate combined with lead citrate. Samples were cut and analyzed with a JEM-1400 transmission electron microscope (JEM-1400, JEOL, Japan).

\subsection{Reactive oxygen species (ROS) detection}

ROS assay kit was used according to the manufacturer's instructions. $2 \times 10^{7}$ glioblastoma cells were incubated with $\mathrm{N} 45(0,4 \mu \mathrm{g} / \mathrm{mL})$ for $24 \mathrm{~h}$, then the cells were harvested, the cells were washed twice more with PBS and loaded with $10 \mu \mathrm{M}$ 2', 7'-Dichlorodi-hydrofluorescein diacetate (DCFH-DA) in serum-free medium for $30 \mathrm{~min}$ at $37^{\circ} \mathrm{C}$ in the dark. After washing three more times with PBS, the samples were analyzed for fluorescence by flow cytometer, with excitation at $485 \mathrm{~nm}$ and emission at 525 $\mathrm{nm}$.

\subsection{Real time cellular analysis (RTCA)}

The proliferation assay and the cell growth index were recorded using iCELLigence system (ACEA Biosciences, Inc. San Diego, CA, USA) as the RTCA system. This system can monitor cell growth status in real time. All monitoring was performed at $37^{\circ} \mathrm{C}$ with regulated $\mathrm{CO}_{2}$ content of 5\%. E-plates (culture plates for the iCELLigence system) containing $200 \mu \mathrm{L}$ culture medium per well were equilibrated to $37^{\circ} \mathrm{C}$, and the cells were seeded at $1 \times 10^{4}$ cells per well in cell culture media.

\subsection{Western blot analysis}

Cells were treated with different doses $(0,4 \mu \mathrm{g} / \mathrm{mL}$ in medium) of N45 for $24 \mathrm{~h}$, and washed twice in cold PBS. Then the treated cells were collected and lysed in radio immunoprecipitation assay (RIPA) lysis buffer, a bicinchoninic acid (BCA) kit was used to determine protein concentration, and all protein samples were quantified to be the same concentration. Cell lysates were subjected to sodium dodecyl sulfate (SDS)-polyacrylamide gel electrophoresis (PAGE) and transferred onto polyvinylidene difluoride (PVDF) membrane. Then incubated with the primary antibody at $4^{\circ} \mathrm{C}$ overnight after blocking with $5 \%$ non-fat dry milk, and then incubated again with the secondary antibody in the dark for $1 \mathrm{~h}$. The protein level was corrected using glyceraldehyde-3-phosphate dehydrogenase (GAPDH). The band density was quantified by densitometry using Image J software.

\subsection{Statistical analysis}

Results were analyzed by GraphPad Prism software 7.0, and all the data were expressed as mean \pm standard deviation. One-way Analysis of Variance (ANOVA) was used to analyze the multi-group differences, $t$ test was used to examine the differences between two groups. The value of $p<0.05$ suggested that the difference was a statistically significant difference.

\section{Results}

3.1. Established the TMZ-resistant U87 cells (U87R) expressed high MGMT

We successfully cultured U87R cells for 175 days and observed with light microscopy (Figure 1A). Western blot assay was used to evaluate the levels of MGMT. The Western blot result showed that the expression of MGMT proteins in U87R was significantly increased compared with the parental U87 cells ( $p<0.05$ and $p<$ 0.01 ) (Figure 1B), and flow cytometry showed TMZ (100, $200 \mu \mathrm{g} / \mathrm{mL}$ ) could not induce apoptosis in U87R cells (Figure 1C). These results indicated that U87R resistant to TMZ $200 \mu \mathrm{g} / \mathrm{mL}$ doses was successfully established and we observed normal cell morphology under light microscopy.

3.2. N45 exhibited cytotoxicity against general glioblastoma cells in vitro

Light microscopy confirmed that $24 \mathrm{~h}$ treatment with N45 on U87 and U251 cells was the optimal time for this study (Figure 2B). The effect on general glioblastoma cells proliferation with N45 was determined by CCK8 assay. The results showed that compared with control group N45 could significantly decrease the optical density (OD) value of U87 and U251 cells after $24 \mathrm{~h}$ treatment $(p<0.05$ and $p<0.001)$. Respectively, the $\mathrm{IC}_{50}$ values (concentration of drug inhibiting cell growth by $50 \%$ ) of U87 and U251 cells were $3.808 \mu \mathrm{g} / \mathrm{mL}$ and $3.39 \mu \mathrm{g} / \mathrm{mL}$ (Figure 2C). The results revealed that N45 suppressed cell proliferation in a dose dependent manner in U87 and U251 glioblastoma cell lines.

3.3. N45 inhibited the viability of general glioblastoma cells by inducing mitochondrial apoptosis

The TUNEL staining assay showed that, numbers of 
A

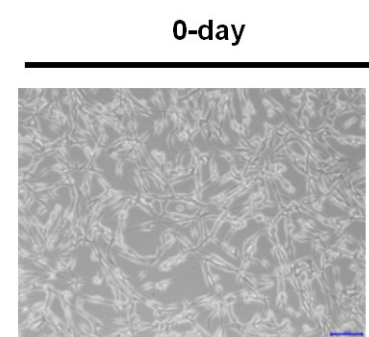

77-day

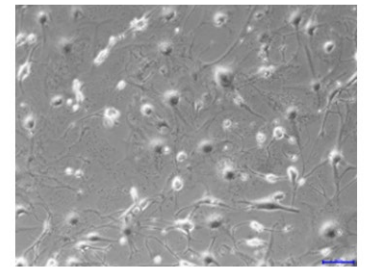

B

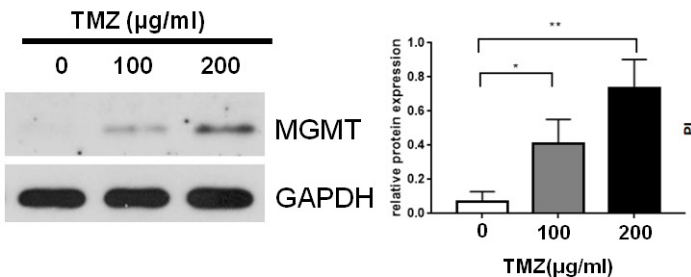

7-day

140-day

C 21-day 63-day
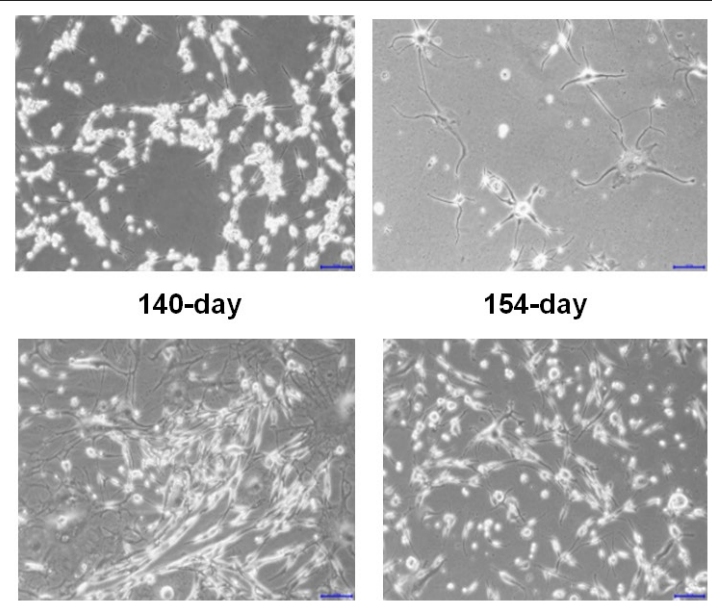

154-day
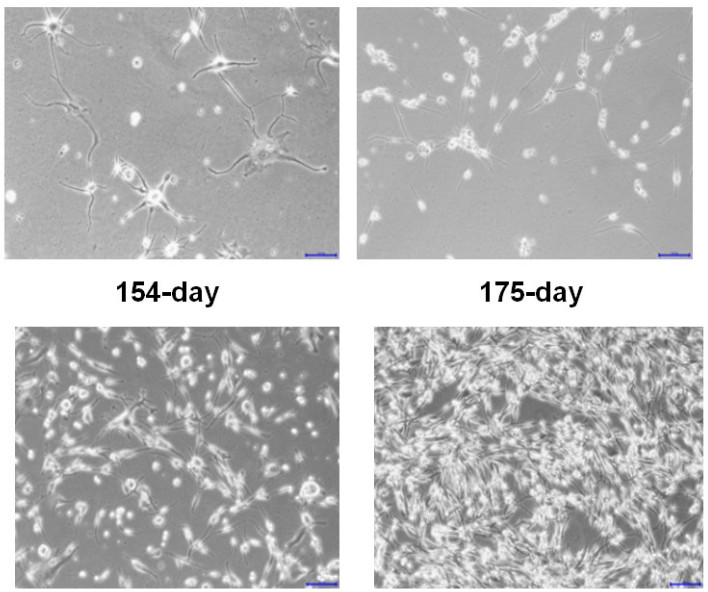

175-day
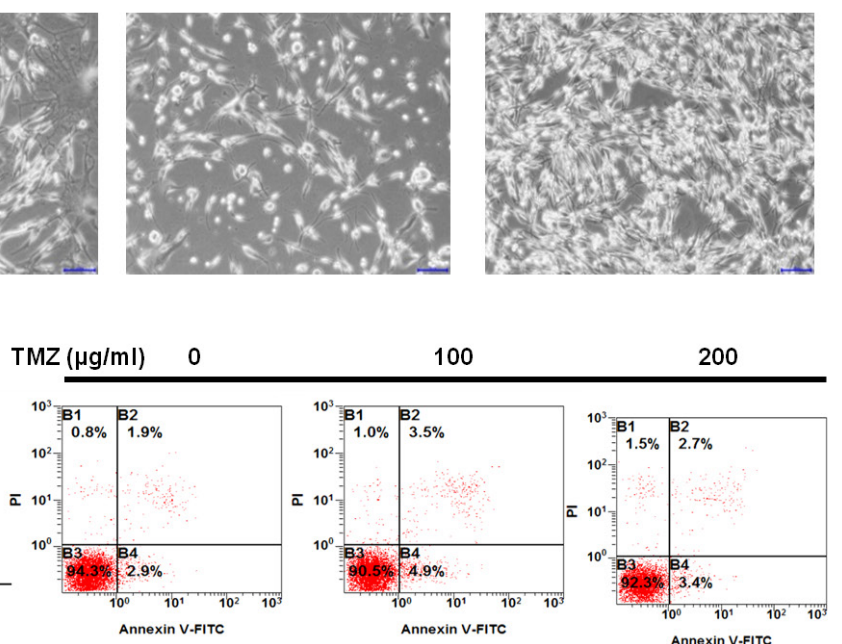

Figure 1. Culture of U87R cell lines (A) The parental cells were treated with repeatedly increased concentrations of TMZ $(1,5,25,50,100 \mu \mathrm{g} / \mathrm{mL})$ for 6 months to establish U87R cells. (B) Western blot assay was used to evaluate the expression of MGMT in parental U87 and U87R (100, $200 \mu \mathrm{g} /$ $\mathrm{mL}$ ) cells, and the density of MGMT was semi-quantitative by Image J software. (C) Annexin V-FITC/PI double staining was used to detect the cell apoptosis rate after treatment with TMZ $(100,200 \mu \mathrm{g} / \mathrm{mL})$ for $24 \mathrm{~h}$. Data is expressed as means \pm SD of three independent experiments. $\left({ }^{*} p<0.05\right.$, $\left.{ }^{* *} p<0.01\right)$, as compared with the control.

A

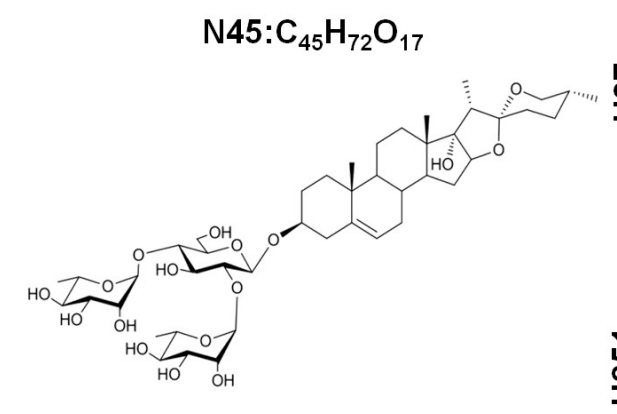

C

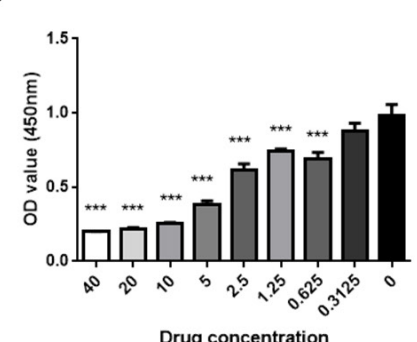

B

U87
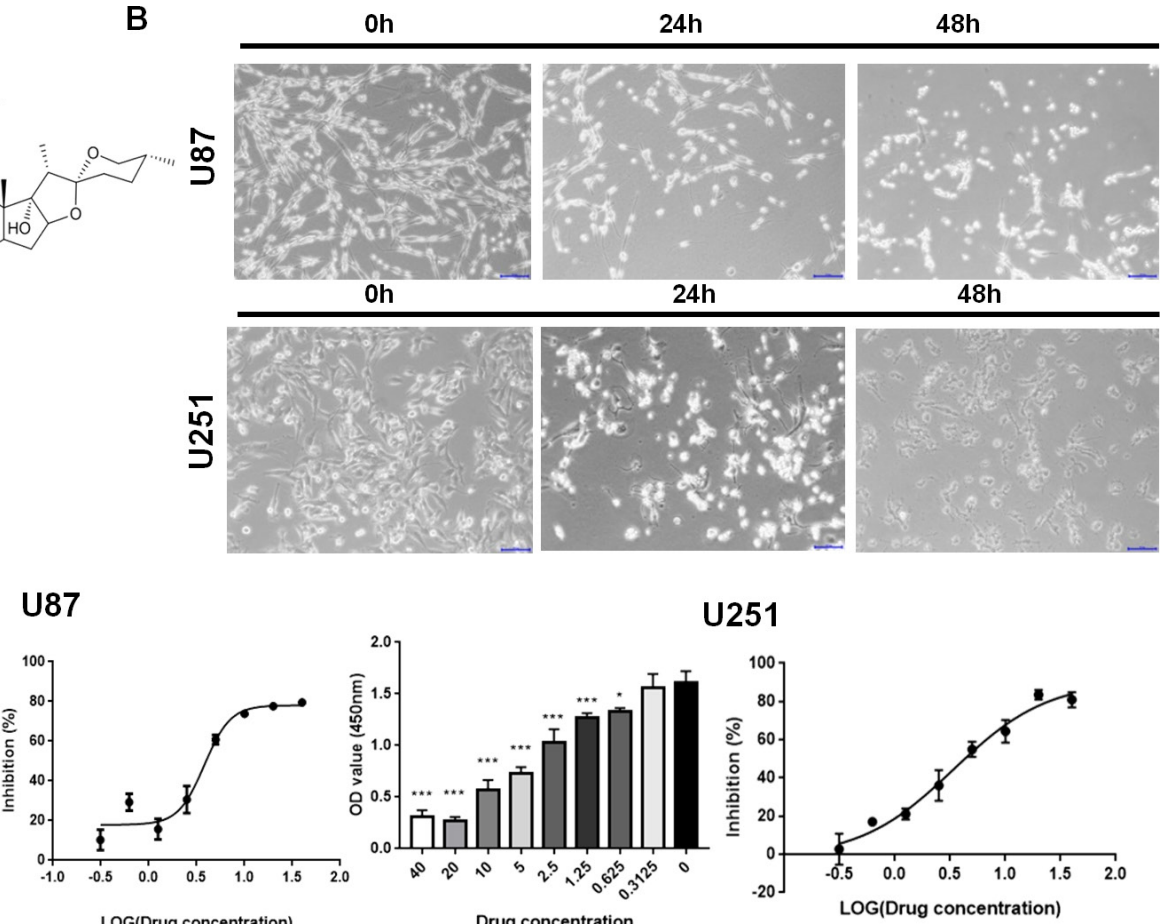

U251
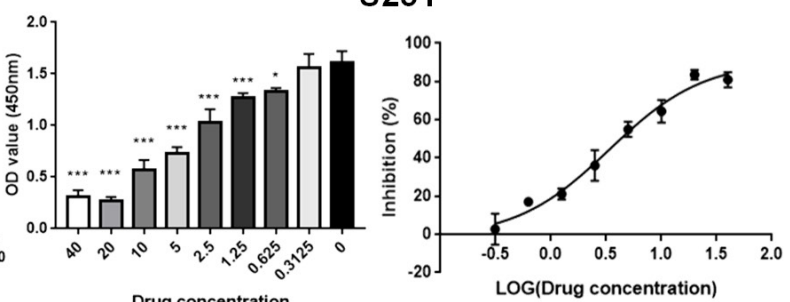

Figure 2. N45 showed cytotoxicity against U87 and U251 cells in a dose dependent manner. (A) Structure of compound N45. (B) U87 and U251 cells morphology were observed under light microscope after treatment with $\mathrm{N} 4510 \mu \mathrm{g} / \mathrm{mL}(24 \mathrm{~h}$ and $48 \mathrm{~h}$ ). (C) U87 and U251 cells were treated with various concentrations of $\mathrm{N} 45$ for $24 \mathrm{~h}$ and the dose response curves of U87 and U251 cells were assessed by CCK 8 assay. Data is expressed as means \pm SD of three independent experiments. $\left({ }^{*} p<0.05,{ }^{* * * *} p<0.001\right)$, as compared with the control group. 
A

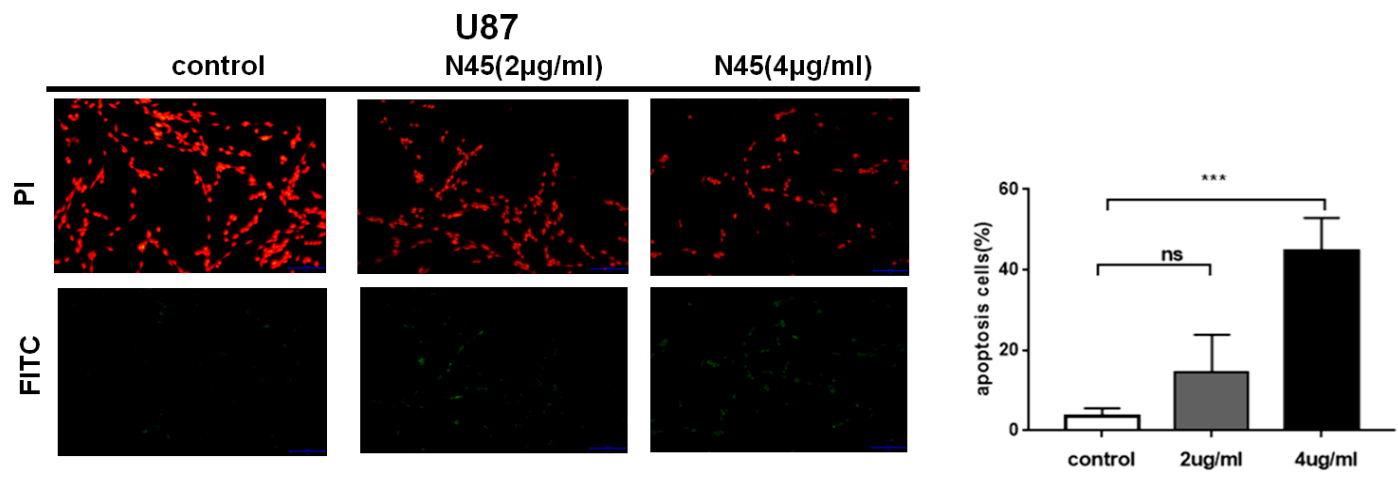

B

$\mathrm{U} 251$

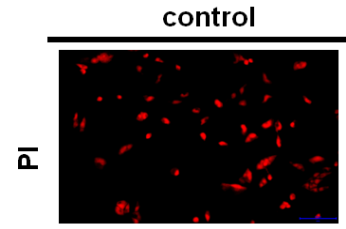

$\mathrm{N} 45(2 \mu \mathrm{g} / \mathrm{ml})$

$\mathrm{N} 45(4 \mu \mathrm{g} / \mathrm{ml})$
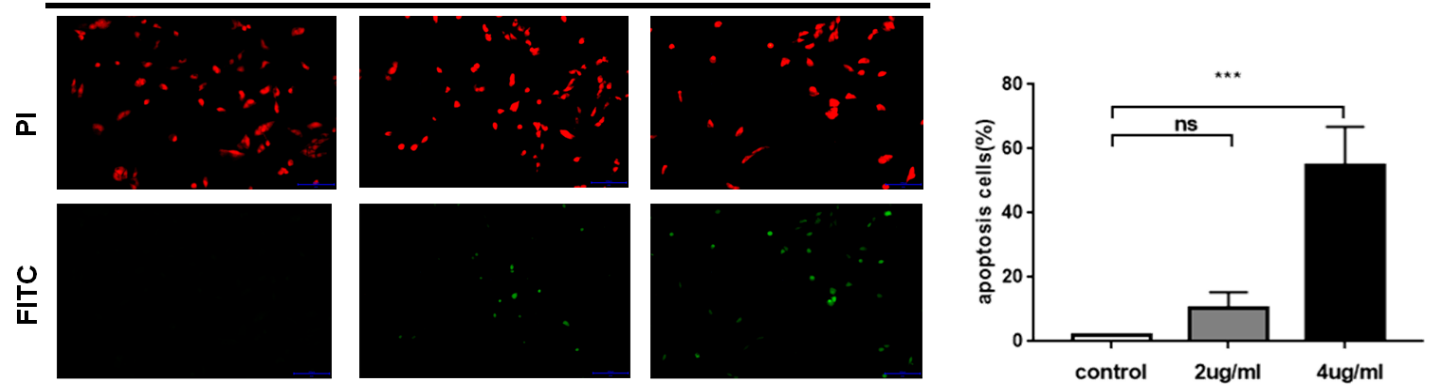

C
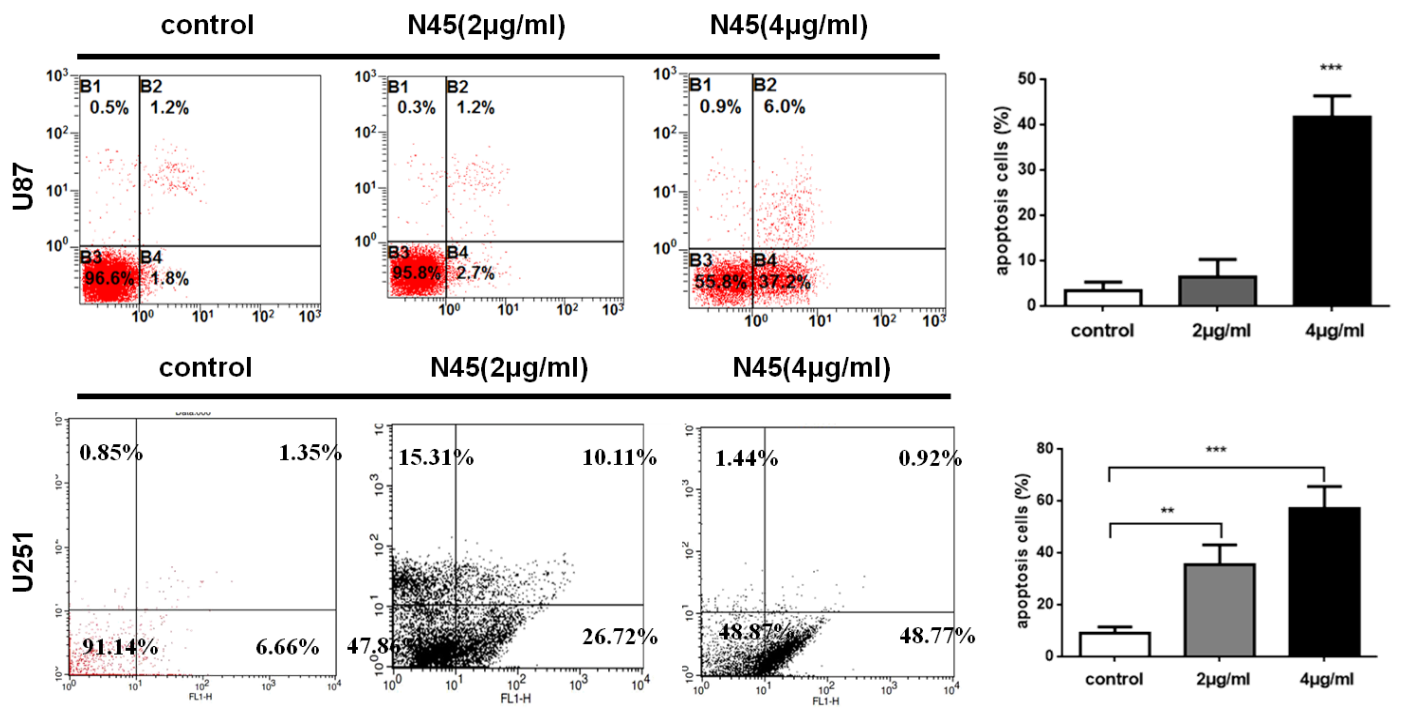

Figure 3. N45 induced apoptosis of U87 and U251 cells. (A) (B) The apoptotic cell rates were determined using TUNEL staining assay after treatment with N45 $(2,4 \mu \mathrm{g} / \mathrm{mL})$ for $24 \mathrm{~h}$. Green fluorescence indicates the apoptotic cells. Red fluorescence indicates both apoptotic and nonapoptotic cells. The histograms present the apoptosis rate (positive cells/total cells). (C) (D) The proportions of living and dead cells were determined using flow cytometry analysis after treatment with $\mathrm{N} 45(2,4 \mu \mathrm{g} / \mathrm{mL})$ for $24 \mathrm{~h}$. The histograms represent the apoptosis rate. Data is expressed as means \pm SD of three independent experiments. $\left(\stackrel{* *}{p} p<0.01\right.$ and $\left.{ }^{* * *} p<0.001\right)$, as compared with the control group. ns, not significant.

green fluorescence cells significantly increased in $4 \mu \mathrm{g} /$ $\mathrm{mL}$ N45 treated U87 and U251 cells compared with the control group $(p<0.001)$ (Figure 3A and B). The flow cytometry assay showed that $4 \mu \mathrm{g} / \mathrm{mL} \mathrm{N} 45$ significantly promoted the percentage of apoptotic cells in the U87 and U251 cells compared with the control group ( $p<$ 0.01 and $p<0.001$ ) (Figure $3 \mathrm{C}$ and D). According to the results expressed in Figure 3, the concentration of $\mathrm{N} 45$ was determined to be $4 \mu \mathrm{g} / \mathrm{mL}$ for the following experiments.

Morphological changes of mitochondria apoptosis were observed using TEM. TEM revealed that, untreated cells exhibited intact cell membranes and normal nuclei, after treatment with N45 the majority of cells had apoptosis features, mainly including cytoplasmic shrinkage, dilation of the ERs, and turgidity of the mitochondrion, disarrangement, diminution and vacuolization (Figure $4 \mathrm{~A}$ and $\mathrm{B}$ ).

Furthermore, we detected expression of mitochondrial apoptosis-related proteins. Western blot showed that, after treatment with N45 $(4 \mu \mathrm{g} / \mathrm{mL})$ for 24 hours, the expressions of caspase 3 , cleaved-caspase 3 and cytochrome $\mathrm{c}$, and the value of $\mathrm{Bax} / \mathrm{Bcl}-2$ were significantly increased $(p<0.01$ and $p<0.001)$ (Figure 
A
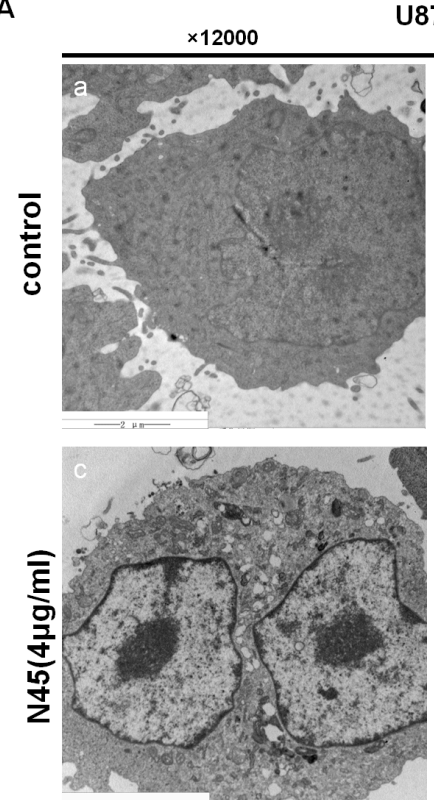

387
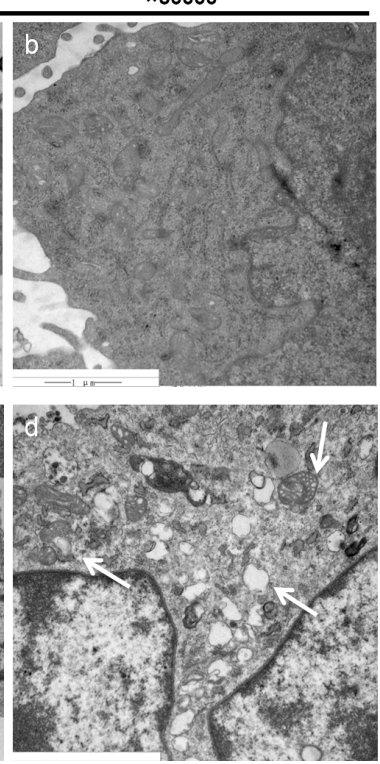

B
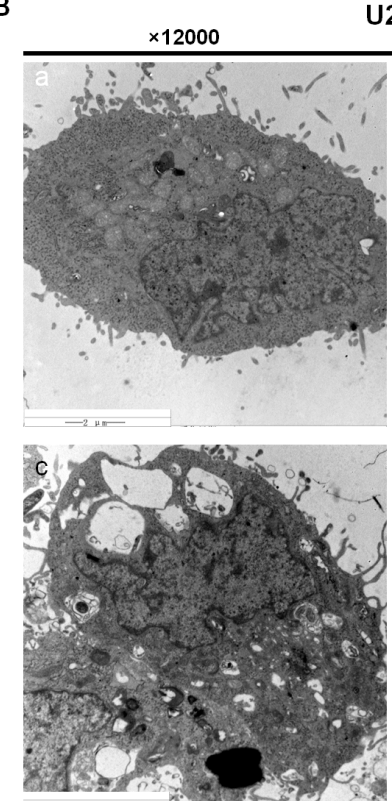

$\mathrm{U} 251$
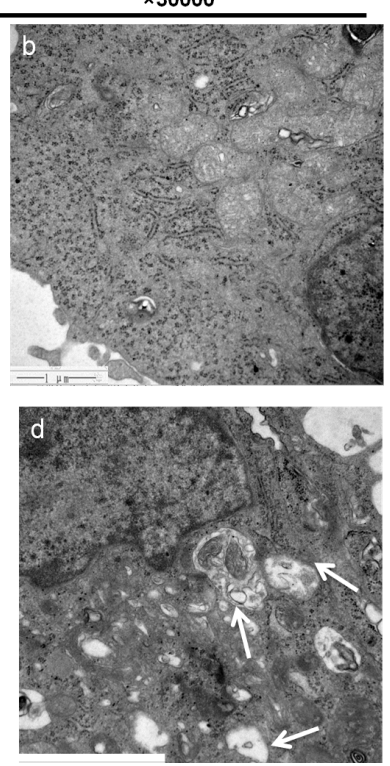

Figure 4. The mitochondria morphological changes of U87 and U251 cells. TEM was used to determine the morphological changes after treatment with N45 $(4 \mu \mathrm{g} / \mathrm{mL})$. (A) (B) Cytoplasmic shrinkage, the dilation of the ERs, and turgidity of the mitochondrion, the disarrangement and vacuolization are shown as arrows.

A
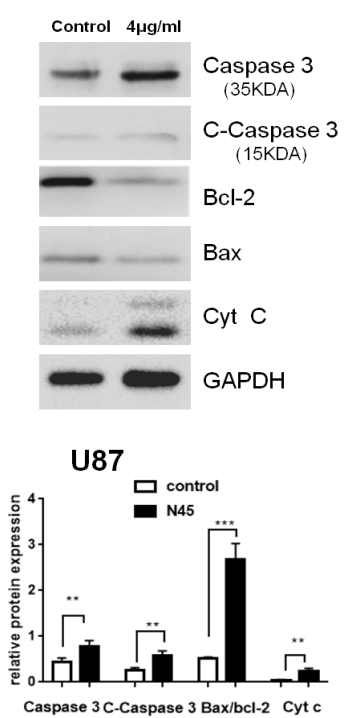

B
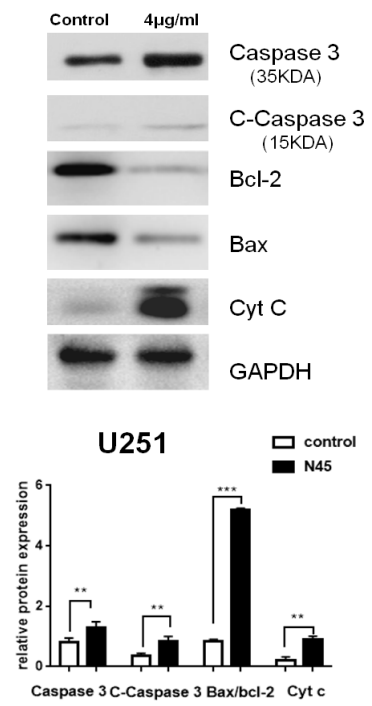

Figure 5. N45 induced mitochondrial apoptosis in U87 and U251 cells. After treatment with $\mathrm{N} 45(4 \mu \mathrm{g} / \mathrm{mL})$ for $24 \mathrm{~h}$, the expression of Bax/Bcl-2, Caspase 3, Cleaved-Caspase 3 and cytochrome $\mathrm{c}$ in the U87 (A), and U251 (B) were analyzed by Western blot, the relative density was semi-quantitative by Image $\mathbf{J}$ software. Data is expressed as means $\pm \mathrm{SD}$ of three independent experiments. $\left({ }^{* *} p<0.01\right.$ and ${ }^{* * * *} p$ $<0.001)$, as compared with the control group.

$5 \mathrm{~A}$ and $\mathrm{B})$. These results demonstrated that $\mathrm{N} 45$ induced mitochondrial apoptosis in U87 and U251 cells.

\subsection{N45 induced mitochondrial apoptosis in U87R cells}

CCK-8 assay and RTCA assay were performed to explore the effect of N45 on U87R cells. The results of CCK8 assay showed that compared with control group, N45 significantly decreased the proliferation of U87R cells

(24 h) in a dose dependent manner $(p<0.001)$ (Figure $6 \mathrm{~A})$. Furthermore, the iCELLigence system revealed that the logarithmic phase U87R cells were given N45 $(4 \mu \mathrm{g} /$ $\mathrm{mL})$ at $125 \mathrm{~h}$. The cell index of U87R decreased rapidly, and viability of U87R cells was inhibited in a short time compared with the control group (Figure 6B). TUNEL staining assay showed that, after treatment with N45 (4 $\mu \mathrm{g} / \mathrm{mL}$ ) for $24 \mathrm{~h}$, the numbers of green fluorescence cells significantly increased compared with control group ( $p$ $<0.01$ ) (Figure 6C). The flow cytometry assay showed that, $4 \mu \mathrm{g} / \mathrm{mL}$ N45 significantly increased the percentage of apoptotic cells in the U87R cells compared with the control group $(p<0.001)$ (Figure 6D). TEM observed that untreated cells exhibited intact cell membranes and normal nuclei, while after treatment with $\mathrm{N} 45(4 \mu \mathrm{g} /$ $\mathrm{mL}$ ) for $24 \mathrm{~h}$, the majority of cells showed dilation of the ERs, turgidity of the mitochondrion, disarrangement, diminution and vacuolization (Figure 7A). Western blot showed that, the U87R cells after treatment with N45 (4 $\mu \mathrm{g} / \mathrm{mL}$ ) for $24 \mathrm{~h}$, the expressions of caspase 3, c-caspase 3 and cytochrome $\mathrm{c}$, and the value of $\mathrm{Bax} / \mathrm{Bcl}-2$ were significantly increased $(p<0.01)$ (Figure 7B). These results revealed that N45 suppressed the cell viability of TMZ-resistant glioblastoma cells in a dose dependent manner, and induced mitochondrial apoptosis.

\subsection{N45 reduced MGMT in U87R cells}

Western blots were used to detect the resistance indicator proteins. Western blot showed that, the level of MGMT and NF- $\mathrm{KB}$ p 65 were significantly increased in the U87R group compared with the parental U87 cells. After treatment with $\mathrm{N} 45(4 \mu \mathrm{g} / \mathrm{mL})$ for $24 \mathrm{~h}, \mathrm{~N} 45$ downregulated the level of MGMT and NF-kB p65 in U87R 
A

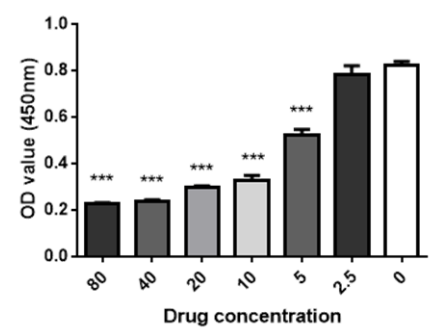

C $\overline{\mathbf{2}}$
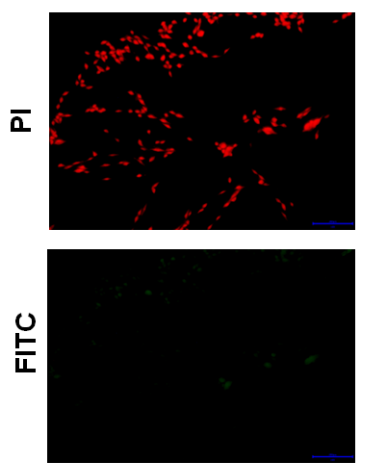

D
B

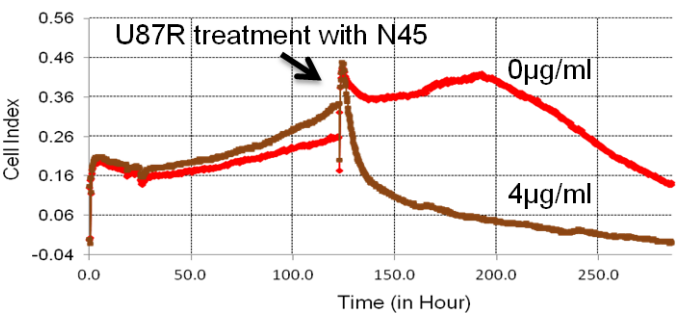

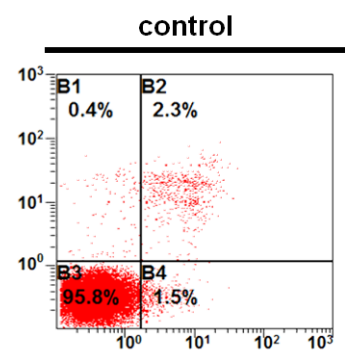
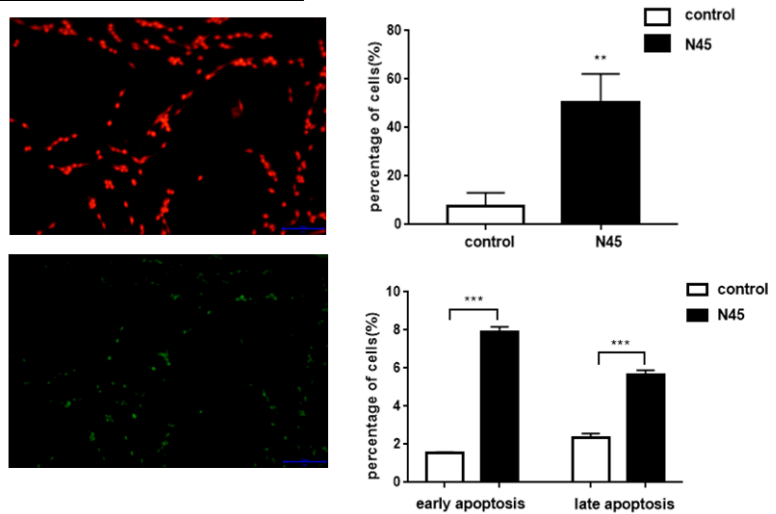

$\mathrm{N} 45(4 \mu \mathrm{g} / \mathrm{ml})$

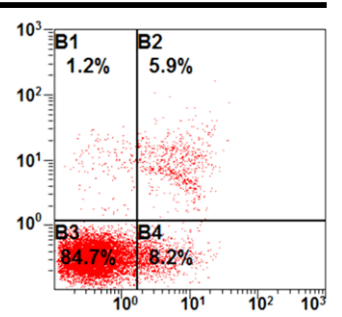

Figure 6. N45 showed cytotoxicity against U87R cells in a dose dependent manner. (A) U87R cells were treated with various concentrations of $\mathrm{N} 45$ for $24 \mathrm{~h}$ and cell viability was assessed by CCK8 assay. (B) The cell growth index was recorded using iCELLigence system. U87R was treated with $\mathrm{N} 45(125 \mathrm{~h})$ and decreased in a short time. (C) The apoptotic cell rates were determined using TUNEL staining assay after treatment with N45 $(4 \mu \mathrm{g} / \mathrm{mL})$ for $24 \mathrm{~h}$. The histograms represent the apoptosis rate (positive cells/total cells). (D) The proportions of living and dead cells were determined using flow cytometry analysis after treatment with $\mathrm{N} 45(4 \mu \mathrm{g} / \mathrm{mL})$ for $24 \mathrm{~h}$. The histograms represent the percentage of early apoptosis and late apoptosis. Data is expressed as means $\pm \mathrm{SD}$ of three independent experiments. ( ${ }^{* *} p<0.01$ and $\left.{ }^{* * *} p<0.001\right)$, as compared with the control group.

A
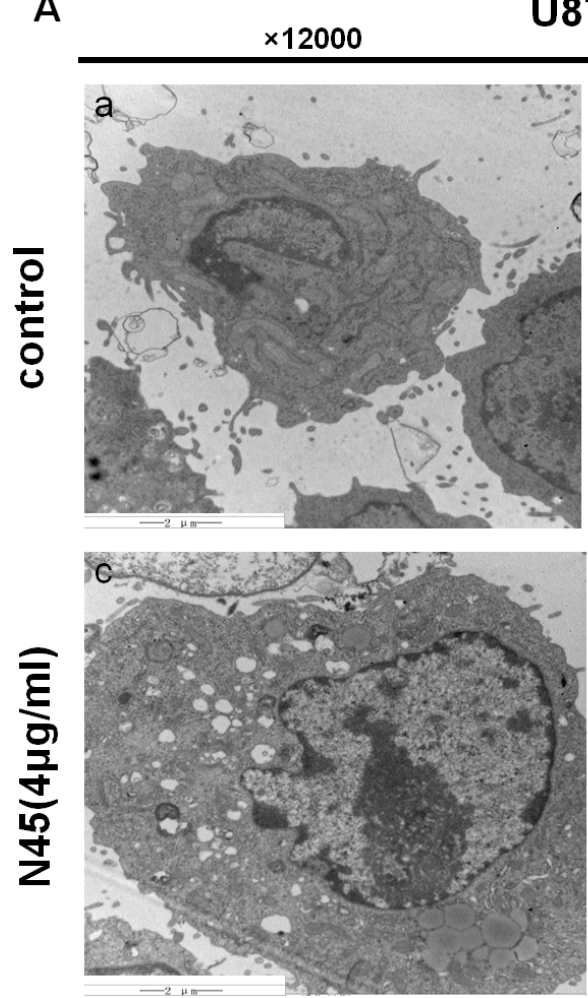

U87R
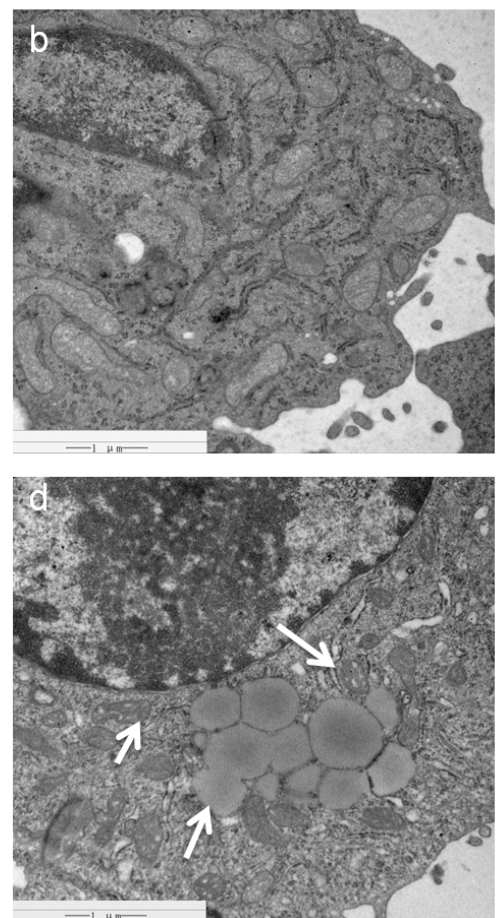

B
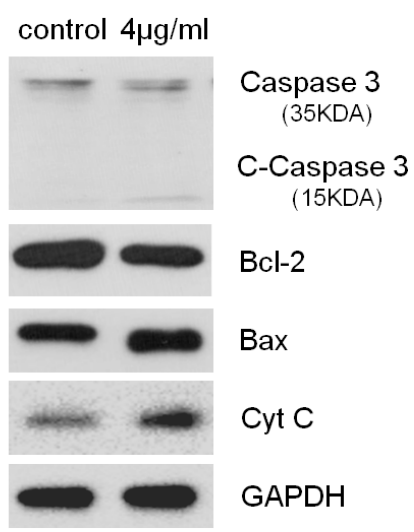

$\mathrm{Bcl}-2$

Bax

Cyt C

GAPDH

\section{U87R}

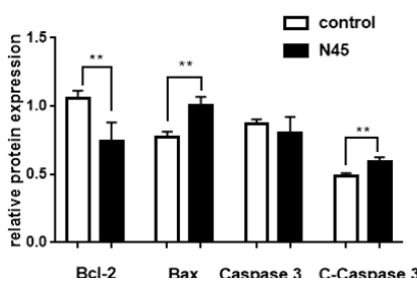

Figure 7. N45 induced mitochondrial apoptosis in U87R cells. (A) TEM was used to determine the morphological changes of U87R cells. Cytoplasmic shrinkage, the dilation of the ERs, and turgidity of the mitochondrion, the disarrangement and vacuolization are shown as arrows. (B) After treatment with $\mathrm{N} 45(4 \mu \mathrm{g} / \mathrm{mL})$ for $24 \mathrm{~h}$, the expression of Bax, Bcl-2, Caspase 3, Cleaved-Caspase 3 and cytochrome c in the U87R cells were analyzed by Western blot. The relative density was semi-quantitative by Image $\mathbf{J}$ software. Data is expressed as means $\pm \mathrm{SD}$ of three independent experiments. $\left({ }^{* *} p<0.01\right)$, as compared with the control group. 
cells compared with the U87R N45 group ( $p<0.05$ and $p<0.01$ ) (Figure 8A). These results suggested N45 down-regulated the expression of the drug resistance related proteins (MGMT), and indicated that N45 could reduce $\mathrm{TMZ}$ resistance.

3.6. N45 induced mitochondrial apoptosis through ROS-mediated inactivation of PI3K/Akt signal pathway

In order to determine whether intracellular ROS involved

A
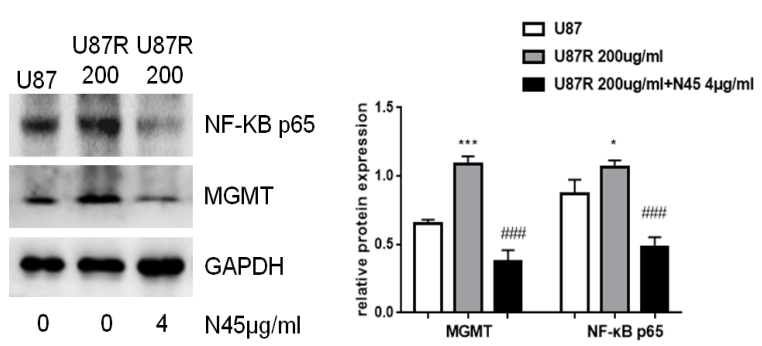

Figure 8. N45 reduced MGMT in U87R cells. (A) The expression of MGMT and NF- $\mathrm{kB}$ p65 in the parental U87 cells group, U87R cells group and U87R cells $+\mathrm{N} 45(4 \mu \mathrm{g} / \mathrm{mL})$ group were analyzed by Western blot, the relative density was semi-quantitative by Image $\mathrm{J}$ software. Data is expressed as means $\pm \mathrm{SD}$ of three independent experiments. $\left({ }^{*} p<0.05\right.$ and ${ }^{* * *} p<0.001$ vs. the control group. ${ }^{\# \#} p<0.001$ $v s$. the $\mathrm{N} 45$ treated group) mitochondrial apoptosis in U87, U251 and U87R cells, intracellular ROS was assessed after $24 \mathrm{~h}$ and measured using flow cytometry assay. The results showed that N45 $(4 \mu \mathrm{g} / \mathrm{mL})$ treatment increased the levels of intracellular ROS compared with control group (Figure 9A). Western blot showed that, after treatment with N45 (4 $\mu \mathrm{g} / \mathrm{mL}$ ) for 24 hours, the expression of PI3K, Akt and phosphorylated Akt (p-Akt) were significantly decreased in U87, U251 and U87R cells ( $p<0.05, p<0.01$ and $p<$ 0.001) (Figure 9C-E).

3.7. NAC (ROS scavenger) counteract N45-mediated mitochondrial apoptosis

The CCK8 assay showed that, the cell viability of N45 $(4 \mu \mathrm{g} / \mathrm{mL})+\mathrm{NAC}(4 \mathrm{mg} / \mathrm{ml})$ group was higher than the N45 $(4 \mu \mathrm{g} / \mathrm{mL})$ group, and indicated that NAC reversed the N45 inhibition in U87, U251 and U87R cells (Figure 9B). Western blot showed that, in the N45 $(4 \mu \mathrm{g} / \mathrm{mL})+$ NAC (4 mg/mL) group, the levels of PI3K and p-Akt were up regulated compared with the N45 $(4 \mu \mathrm{g} / \mathrm{mL})$ treatment group $(p<0.01$ and $p<0.001)$ (Figure 9C-E). These results demonstrated that ROS were negatively correlated with the PI3K/Akt pathway. Moreover, the NAC effectively reduced N45-mediated apoptosis in U87, U251 and U87R cells.

A

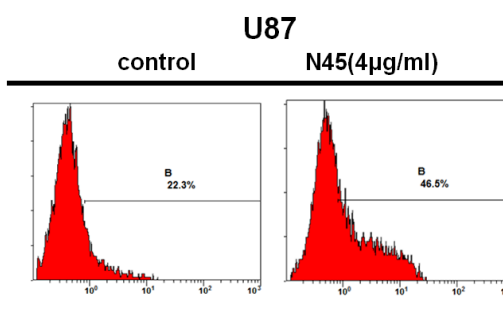

B

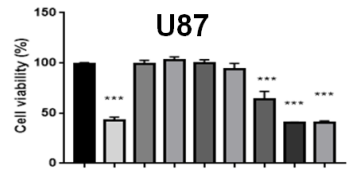

$\begin{array}{llllllllll}\mathrm{N} 45(4 \mu \mathrm{g} / \mathrm{ml}) & - & + & - & + & + & + & + & + & + \\ \mathrm{NAC}(\mathrm{mg} / \mathrm{ml}) & - & - & 16 & 16 & 8 & 4 & 2 & 1 & 0.5\end{array}$

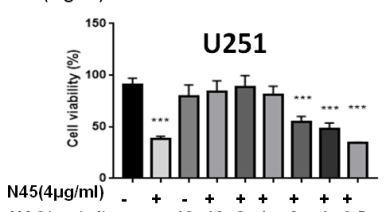

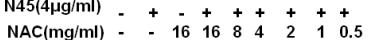

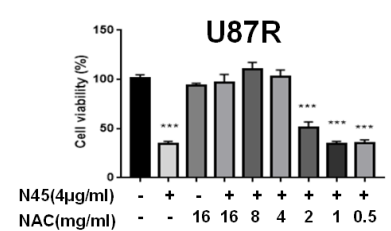

C

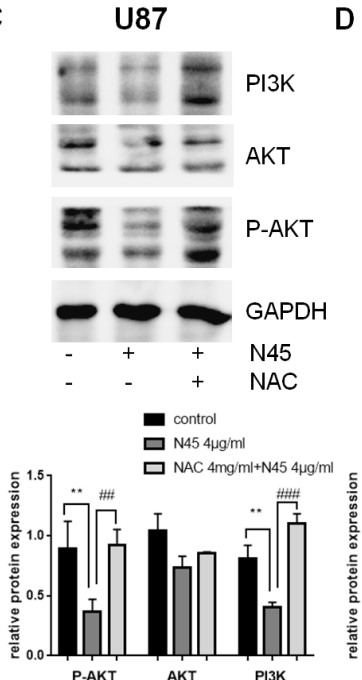

$\mathrm{U} 251$ $\mathrm{N} 45(4 \mu \mathrm{g} / \mathrm{ml})$

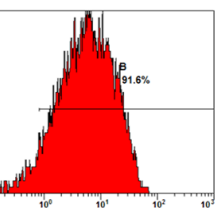

U251

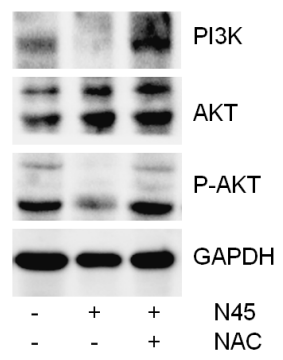

E

U87R

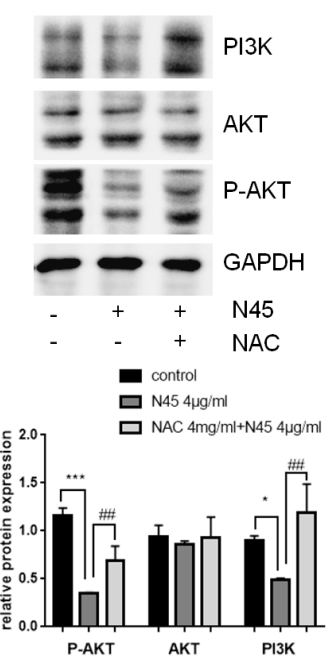

Figure 9. Effects of N45 on ROS/PI3K/Akt signaling pathway in U87, U251 and U87R cells. (A) Intracellular ROS were assessed by flow cytometry after treatment with N45 $(4 \mu \mathrm{g} / \mathrm{mL})$ for $24 \mathrm{~h}$, the relative fluorescence percentage was used to estimate intracellular ROS increase. (B) The CCK8 assay determined that $4 \mathrm{mg} / \mathrm{mL}$ NAC was the optimal dose, in combination with N45 and could reverse the inhibition in U87, U251 and U87R cells. (C-E) Cells were treated with N45 (4 $\mathrm{gg} / \mathrm{mL})$ and N45 $(4 \mu \mathrm{g} / \mathrm{mL})+\mathrm{NAC}(4 \mathrm{mg} / \mathrm{ml})$ for $24 \mathrm{~h}$. the expression of PI3K, Akt and p-Akt in the U87, U251 and U87R cells were analyzed by Western blot, the relative density was semi-quantitative by Image J software. Data is expressed as means $\pm \mathrm{SD}$ of three independent experiments. $\left({ }^{*} p<0.05,{ }^{* * *} p<0.01\right.$ and ${ }^{* * * *} p<0.001 v s$. the control group. ${ }^{\#} p<0.01$ and ${ }^{\# \# \#} p<0.001 v s$. the N45 treated group). 


\section{Discussion}

Natural products are a main resource for leading compounds for new drug discovery, which have played a critical role in cancer therapy and chemoprevention study. Steroidal saponins with the character of resource diversity, structural diversity and bioactive diversity have become an important branch of natural drug discovery and one of the most likely sources of innovative drugs in the future. The work undertaken by our team has isolated many anti-tumor saponins from many plants and animals, such as Paris vietnamensis (22), Culcita novaeguineae (23), and Anthenea chinensis (24), and many of them have demonstrated significant effects on various tumors. Paris vietnamensis (Takht.) is used as a Traditional Chinese Medicine and has been reported to possess preclinical anticancer efficacy in various cancer types $(18,22)$. N45 was isolated from the rhizomes of Paris vietnamensis (Takht.) and was supposed to have a good antitumor effect. In this study, we investigated the antitumor mechanism of N45 on glioblastoma cells and TMZresistant glioblastoma cells.

The results showed that N45 significantly suppressed the cell proliferation of glioblastoma cells in a dose dependent manner (Figure 2C). Furthermore, N45 induced cell apoptosis of U87 and U251 cells, which was verified by TUNEL and flow cytometry experiments (Figure 3A and B). Noticeably, morphological changes of mitochondrial swelling and crista disorder were observed under TEM in U87 and U251 cells, which indicated that mitochondria might be involved in the cell apoptosis induced by N45 (Figure $4 \mathrm{~A}$ and $\mathrm{B}$ ).

The participation of mitochondria in apoptosis is one of the most important cell apoptotic pathways. PI3K is a key signal molecule that regulates the mitochondrial apoptosis pathway. The downstream signal molecule of PI3K signal pathway was mainly related to caspase family, Bax, Bcl-2 family and PI3K, Akt indicators. Akt is activated by phosphorylation and is the primary mediator of PI3K-initiated signaling, while Bcl-2 is a member of its downstream apoptosis-inhibitory molecule $(25,26)$. Apoptosis-inhibitory protein Bcl2 and pro-apoptotic protein Bax are both members of the Bcl-2 family. The ratio of Bax/Bcl-2 is a key factor in balancing mitochondrial apoptosis pathway (27). The inactivation of PI3K/Akt could down-regulate the expression of $\mathrm{Bcl}-2$, in order to change the ratio of $\mathrm{Bax} /$ $\mathrm{Bcl}-2$. Increasing the ratio of $\mathrm{Bax} / \mathrm{Bcl}-2$ could release cytochrome $\mathrm{C}$ from mitochondria to cytoplasm, and then activate caspase 3 , which is an important apoptosis implementing protein. In the current study, N45 decreased the levels of PI3K, p-Akt and Bcl-2, while it increased the expression of cytochrome C, capase 3 , cleaved caspase 3 and the ratio of $\mathrm{Bax} / \mathrm{Bcl}-2$, which resulted in proliferation inhibition and cell apoptosis in U87 (Figure 5A, Figure 9C) and U251 cells (Figure 5B, Figure 9D). The results revealed that N45 inhibited proliferation and induced mitochondrial apoptosis in glioblastoma cells through the PI3K/Akt pathway.

Intracellular ROS are mainly produced from mitochondria. Intracellular or extracellular stimuli lead to intracellular ROS production and increased membrane permeabilization, whereas excessively high levels of ROS promote cell apoptosis by activating internal and external pathways (28). ROS interact with many factors that directly affect cell viability and promote cell death, thus, ROS are widely studied as antitumor agents (29). Previous studies have reported several bioactive compounds generated ROS to activate apoptosis signaling in cancer cells, while ROSdependent compounds suppressed the activity of the PI3K/Akt signaling pathway. Fucoxanthin induced apoptosis in human glioblastoma cells via triggering of ROS-mediated oxidative damage and regulation of MAPKs and PI3K-Akt pathways (30). Thioridazine enhanced TRAIL-mediated apoptosis via the ROSmediated inhibition of Akt signaling in renal carcinoma Caki cells (31). In this paper, N45 increased ROS generation, which was observed by flow cytometry experiments (Figure 9A). NAC, a ROS scavenger, was used for the following rescue experiments. A CCK-8 experiment showed that NAC significantly attenuated the proliferation inhibition effect of N45 in U87 and U251 cells (Figure 9B). Moreover, NAC also reversed the levels of PI3K and p-Akt, both of which were the primary mediator of PI3K-initiated signaling (Figure 9C and D). That confirmed N45 induced glioblastoma cells' mitochondrial apoptosis via ROS-mediated inactivation of PI3K/Akt.

TMZ is the first-line chemotherapy drug for glioblastoma and possesses a relatively good efficacy. However, in recent years endogenous or acquired resistance to TMZ limits its efficacy in the therapy of glioblastoma. TMZ-induced injury can be repaired by $\mathrm{O}^{6}$-methylguanine-DNA methyltransferase (MGMT), which is a DNA repair enzyme and plays a key role in TMZ resistance and has now been commonly recognized (32). These findings suggested that reducing the expression of MGMT might be an effective therapeutic strategy in TMZ-resistant cancers. Previous studies reported reducing MGMT expression to augment chemo-sensitivity to TMZ and induced cell apoptosis in cancers. Lingchao Chen et al. (33) and Mao Li et al. (34) showed that the PI3K inhibitor (BKM120 and LY294002) could reduce MGMT, and overcome TMZ resistance sensitivity in glioblastoma cells via suppression of the PI3K/Akt signaling pathway. However, there are few studies on steroid saponins to reverse TMZ resistance. Thus, we cultured U87R cells to test the effect of N45 on TMZ-resistant glioblastoma, the result of Figure 1 showed that TMZ-resistant glioblastoma cells were successfully established. The 
results of CCK-8, TUNEL, flow cytometry, TEM and iCELLigence systems confirmed that N45 inhibited proliferation and induced mitochondrial apoptosis in U87R cells (Figure 6A-D, Figure 7A). Western blots revealed that $\mathrm{N} 45$ treated U87R cells reacted the same as it worked in U87 and U251 cells (Figure 7B, Figure 9E). The results of rescue experiments also confirmed N45 induced mitochondrial apoptosis via ROSmediated inactivation of PI3K/Akt signal pathway in U87R cells.

$\mathrm{NF}-\mathrm{\kappa B}$ is a member substrate in the downstream PI3K/Akt pathway, which contributes to the resistance of chemotherapy. NF-kB p65, a transcription factor, is the key subunit in the NF- $\mathrm{kB}$ family (35-37). In glioblastoma cells, due to the over-activation of PI3K/Akt signaling pathway, NF- $\mathrm{kB}$ p 65 translocated into the nucleus and subsequently initiated transcription of numerous genes, including MGMT $(33,38)$. In this paper, U87R cells significantly expressed NF- $\mathrm{\kappa B}$ p65 and MGMT. After treatment with N45, the expression of MGMT and NF$\kappa \mathrm{B}$ p65 was decreased compared with the untreated U87R cells (Figure 8A). The results indicated that N45 suppressed TMZ-resistance and induced apoptosis in U87R cells by decreasing the expression of PI3K/Akt and its downstream protein NF- $\kappa B$ p65 to attenuate MGMT.

In conclusions, these results suggest that ROSmediated inactivation of PI3K/Akt played an important role in N45 induced mitochondrial apoptosis in glioblastoma cells and TMZ-resistant glioblastoma cells.

\section{Acknowledgements}

This study was supported by the National Natural Science Foundation of China (No. 81973192 and No.81903862), and Shaanxi Provincial Administration of Traditional Chinese Medicine (No. ZYMS012).

Statement of Ethics This investigation was approved by the Institutional Review Board of Tangdu Hospital, Fourth Military Medical University.

\section{References}

1. Lapointe S, Perry A, Butowski NA. Primary brain tumours in adults. Lancet. 2018; 392:432-446.

2. Palanichamy K, Erkkinen M, Chakravarti A. Predictive and prognostic markers in human glioblastomas. Curr Treat Options Oncol. 2006; 7:490-504.

3. Stupp R, Hegi ME, van den Bent MJ, Mason WP, Weller M, Mirimanoff RO, Cairncross JG, European Organisation for Research and Treatment of Cancer Brain Tumor and Radiotherapy Groups, National Cancer Institute of Canada Clinical Trials Group. Changing paradigms--an update on the multidisciplinary management of malignant glioma. Oncologist. 2006; 11:165-180.

4. Mrugala MM. Advances and challenges in the treatment of glioblastoma: a clinician's perspective. Discov Med. $2013 ; 15: 221-230$.
5. Fan TY, Wang H, Xiang P, Liu YW, Li HZ, Lei BX, Yu M, Qi ST. Inhibition of EZH2 reverses chemotherapeutic drug TMZ chemosensitivity in glioblastoma. Int J Clin Exp Pathol. 2014; 7:6662-6670.

6. Galic VL, Wright JD, Lewin SN, Herzog TJ. Paclitaxel poliglumex for ovarian cancer. Expert Opin Investig Drugs. 2011; 20:813-821.

7. Megerdichian C, Olimpiadi Y, Hurvitz SA. nab-Paclitaxel in combination with biologically targeted agents for early and metastatic breast cancer. Cancer Treat Rev. 2014; 40:614-625.

8. Xiang L, Yi X, Wang Y, He X. Antiproliferative and antiinflammatory polyhydroxylated spirostanol saponins from Tupistra chinensis. Sci Rep. 2016; 6:31633.

9. Khan M, Maryam A, Zhang H, Mehmood T, Ma T. Killing cancer with platycodin D through multiple mechanisms. J Cell Mol Med. 2016; 20:389-402.

10. Zheng M, Zhao M, Tang L, Zhang C, Song L, Wang W. Ginsenoside $\operatorname{Rg} 1$ attenuates hypoxia and hypercapniainduced vasoconstriction in isolated rat pulmonary arterial rings by reducing the expression of $\mathrm{p} 38$. J Thorac Dis. 2016; 8:1513-1523.

11. Park EH, Kim YJ, Yamabe N, Park SH, Kim HK, Jang HJ, Kim JH, Cheon GJ, Ham J, Kang KS. Stereospecific anticancer effects of ginsenoside $\mathrm{Rg} 3$ epimers isolated from heat-processed American ginseng on human gastric cancer cell. J Ginseng Res. 2014; 38:22-27.

12. Cheong JH, Kim H, Hong MJ, Yang MH, Kim JW, Yoo H, Yang H, Park JH, Sung SH, Kim HP, Kim J. Stereoisomer-specific anticancer activities of ginsenoside $\mathrm{Rg} 3$ and Rh2 in HepG2 cells: disparity in cytotoxicity and autophagy-inducing effects due to 20(S)-epimers. Biol Pharm Bull. 2015; 38:102-108.

13. Liu T, Zhao L, Zhang Y, Chen W, Liu D, Hou H, Ding L, Li X. Ginsenoside 20(S)-Rg3 targets HIF-1 $\alpha$ to block hypoxia-induced epithelial-mesenchymal transition in ovarian cancer cells. PLoS One. 2014; 9:e103887.

14. Park D, Bae DK, Jeon JH, et al. Immunopotentiation and antitumor effects of a ginsenoside $\mathrm{Rg} 3$-fortified red ginseng preparation in mice bearing H460 lung cancer cells. Environ Toxicol Pharmacol. 2011; 31:397-405.

15. Shan X, Tian LL, Zhang YM, Wang XQ, Yan Q, Liu JW. Ginsenoside Rg3 suppresses FUT4 expression through inhibiting NF- $\kappa \mathrm{B} / \mathrm{p} 65$ signaling pathway to promote melanoma cell death. Int J Oncol. 2015; 47:701-709.

16. Wang YH, Shi M, Niu HM, Yang J, Xia MY, Luo JF, Chen YJ, Zhou YP, Li H. Substituting one Paris for another? In vitro cytotoxic and in vivo antitumor activities of Paris forrestii, a substitute of Paris polyphylla var. yunnanensis. J Ethnopharmacol. 2018; 218:45-50.

17. Li, H. The Genus Paris (Trilliaceae). Science Press, Beijing, China, 1998; pp. 26-28. (in Chinese)

18. Wei JC, Gao WY, Yan XD, Wang Y, Jing SS, Xiao PG. Chemical constituents of plants from the genus Paris. Chem Biodivers. 2014; 11:1277-1297.

19. Xu XH, Li T, Fong CM, Chen X, Chen XJ, Wang YT, Huang MQ, Lu JJ. Saponins from Chinese Medicines as Anticancer Agents. Molecules. 2016; 21:E1326.

20. Liu J, Zhang Y, Chen L, Yu F, Li X, Dan Tao, Zhao J, Zhou S. Polyphyllin I induces G2/M phase arrest and apoptosis in U251 human glioma cells via mitochondrial dysfunction and the JNK signaling pathway. Acta Biochim Biophys Sin (Shanghai). 2017; 49:479-486.

21. Pang D, Li C, Yang C, Zou Y, Feng B, Li L, Liu W, Geng Y, Luo Q, Chen Z, Huang C. Polyphyllin VII 
Promotes Apoptosis and Autophagic Cell Death via ROS-Inhibited AKT Activity, and Sensitizes Glioma Cells to Temozolomide. Oxid Med Cell Longev. 2019; 2019:1805635.

22. Liu Y, Wang M, Liu K, Qiu P, Zhang S, Lu Y, Tang N, Tang H. New Steroidal Saponins from the Rhizomes of Paris vietnamensis and Their Cytotoxicity. Molecules. 2018; 23: E588

23. Cheng G, Zhang X, Tang HF, Zhang Y, Zhang XH, Cao WD, Gao DK, Wang XL, Jin BQ. Asterosaponin 1, a cytostatic compound from the starfish Culcita novaeguineae, functions by inducing apoptosis in human glioblastoma U87MG cells. J Neurooncol. 2006; 79:235241.

24. Ma N, Tang HF, Qiu F, Lin HW, Tian XR, Yao MN. Polyhydroxysteroidal glycosides from the starfish Anthenea chinensis. J Nat Prod. 2010; 73:590-597.

25. Manning BD, Cantley LC. AKT/PKB signaling: navigating downstream. Cell. 2007; 129:1261-1274.

26. Yang E, Korsmeyer SJ. Molecular thanatopsis: a discourse on the BCL2 family and cell death. Blood. 1996; 88:386401.

27. Gao C, He XF, Xu QR, Xu YJ, Shen J. Sevoflurane downregulates insulin-like growth factor-1 to inhibit cell proliferation, invasion and trigger apoptosis in glioma through the PI3K/AKT signaling pathway. Anticancer Drugs. 2019; 30:e0744.

28. Zhou S, Wen H, Li H. Magnolol induces apoptosis in osteosarcoma cells via G0/G1 phase arrest and p53mediated mitochondrial pathway. J Cell Biochem. 2019; 120:17067-17079.

29. Giampazolias E, Tait SW. Mitochondria and the hallmarks of cancer. FEBS J. 2016; 283:803-814.

30. Wu HL, Fu XY, Cao WQ, Xiang WZ, Hou YJ, Ma JK, Wang Y, Fan CD. Induction of Apoptosis in Human Glioma Cells by Fucoxanthin via Triggering of ROSMediated Oxidative Damage and Regulation of MAPKs and PI3K-AKT Pathways. J Agric Food Chem. 2019; 67:2212-2219.

31. Min KJ, Seo BR, Bae YC, Yoo YH, Kwon TK. Antipsychotic agent thioridazine sensitizes renal carcinoma Caki cells to TRAIL-induced apoptosis through reactive oxygen species-mediated inhibition of Akt signaling and downregulation of Mcl-1 and c-FLIP(L). Cell Death Dis. 2014; 5:e1063.
32. Lai SW, Huang BR, Liu YS, Lin HY, Chen CC, Tsai CF, Lu DY, Lin C. Differential Characterization of Temozolomide-Resistant Human Glioma Cells. Int J Mol Sci. 2018; 19:E127.

33. Li M, Liang RF, Wang X, Mao Q, Liu YH. BKM120 sensitizes C6 glioma cells to temozolomide via suppression of the PI3K/Akt/NF- $\mathrm{KB} / \mathrm{MGMT}$ signaling pathway. Oncol Lett. 2017; 14:6597-6603.

34. Chen L, Han L, Shi Z, Zhang K, Liu Y, Zheng Y, Jiang T, $\mathrm{Pu}$ P, Jiang C, Kang C. LY294002 enhances cytotoxicity of temozolomide in glioma by down-regulation of the PI3K/Akt pathway. Mol Med Rep. 2012; 5:575-579.

35. Kumar A, Takada Y, Boriek AM, Aggarwal BB. Nuclear factor-kappaB: its role in health and disease. J Mol Med (Berl). 2004; 82:434-448.

36. Van der Heiden K, Cuhlmann S, Luong le A, Zakkar M, Evans PC. Role of nuclear factor kappaB in cardiovascular health and disease. Clin Sci (Lond). 2010; 118:593-605.

37. Senftleben U, Cao Y, Xiao G, Greten FR, Krähn G, Bonizzi G, Chen Y, Hu Y, Fong A, Sun SC, Karin M. Activation by IKKalpha of a second, evolutionary conserved, NF-kappa B signaling pathway. Science. 2001; 293:1495-1499.

38. Zhang LH, Yin AA, Cheng JX, Huang HY, Li XM, Zhang YQ, Han N, Zhang X. TRIM24 promotes glioma progression and enhances chemoresistance through activation of the PI3K/Akt signaling pathway. Oncogene. 2015; 34:600-610.

Received January 9, 2020; Revised February 9, 2020; Accepted February 15, 2020

${ }^{\S}$ These authors contributed equally to this work.

*Address correspondence to:

Haifeng Tang, School of Pharmacy, Shaanxi University of Chinese Medicine, Xianyang 712046, China;

E-mail: tanghaifeng71@163.com

Pengcheng Qiu, Institute of Materia Medica, School of Pharmacy, Fourth Military Medical University, Xi'an 710032, China.

E-mail: qpc023@126.com

Released online in J-STAGE as advance publication March 14, 2020. 